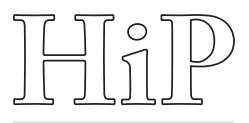

Historia i Polityka

$\mathrm{Nr} 13(20) / 2015$, ss. $183-189$

ISSN 1899-5160

www.hip.umk.pl

DOI: http://dx.doi.org/10.12775/HiP.2015.012

Olga KAPRUS

Lwowski Uniwersytet Narodowy im. Iwana Franki, Ukraina

\title{
Aspekty globalizacyjne działalności Swiatowej Organizacji Turystyki we współczesnych stosunkach międzynarodowych
}

\section{Globalization Trends of the United Nations World Tourism Organization Activities in Contemporary International Relations}

\begin{abstract}
The features of the emergence of globalization trends and the main ways of their influence on the formation of international organizations are analyzed in this article. The UNWTO activities in current globalization processes are highlighted.
\end{abstract}

Keywords: globalization, globalization processes, tourism, international organization, United Nations World Tourism Organization

Słowa kluczowe: globalizacja, procesy globalizacyjne, turystyka, organizacja międzynarodowa, Światowa Organizacja Turystyki Narodów Zjednoczonych

W ciągu ostatnich stu lat nastąpiło wiele zmian które dotyczą prawie wszystkich dziedzin życia. Ważną determinantą tych zmian był rozwój turystyki, który dziś jest integralną częścią polityki państwowej i współpracy międzynarodowej. Rola i znaczenie turystyki w warunkach współczesnych procesów globalizacyjnych aktualizowane są przede wszystkim przez globalną tendencję do internacjonalizacji życia społecznego i politycznego oraz rosnący potencjał gospodarczy działalności turystycznej.

Procesy globalizacyjne powodują istotne zmiany w dziedzinie gospodarki, polityki, technologii itp. Rozwój turystyki przyśpiesza przebieg tych zmian. Kwestie odnoszące się do pojęcia globalizacji, etapów jej powstawania, podstaw koncepcyjnych w kontekście problemów i perspektyw rozwoju turystyki międzynarodowej i Światowej Organizacji Turystyki Narodów Zjednoczonych w znacznym stopniu zwiększyły zainteresowanie tą tematyką licznych badaczy (James Breckenridge ${ }^{1}$,

${ }^{1} \mathrm{~J}$. Breckenridge, Globalization and a Conservative Dilemma: Economic Openness and Retributive Policies, Journal of Social Issues 2012, Vol. 68, Issue 3, s. 559-570. 
Henry Kissinger ${ }^{2}$, Martin Gus ${ }^{3}$, Jürgen Osterhammel ${ }^{4}$, Roland Robertson ${ }^{5}$, Peter Haggett ${ }^{6}$, David Held ${ }^{7}$, Wiesław Sztumski ${ }^{8}$ ). Były również przedmiotem zainteresowania autorów ukraińskich (Oksana Krajewska', Mikola Lukaszewicz ${ }^{10}$, Aleksandr Panarin $^{11}$, Sergej Udowik ${ }^{12}$, Maksimilian Szepyeliew ${ }^{13}$, Jurij Yakowets ${ }^{14}$ i in.). Analiza badań organizacji międzynarodowych pozwala stwierdzić, że zainteresowanie naukowców tą tematyką stale rośnie.

Rola organizacji międzynarodowych we współczesnych stosunkach międzynarodowych coraz bardziej wzrasta. Przyczyną tego są przede wszystkim procesy globalizacyjne. Państwom trudno dostosować się do globalnych rynkowych niepowodzeń bez współpracy i koordynacji. Organizacje międzynarodowe zapewniają wspólną platformę, na której przedstawiciele różnych części świata mają możliwość omówienia bieżących problemów i szukania sposobów ich rozwiązania. Członkostwo w organizacjach międzynarodowych powoduje wiele korzystnych skutków dla poszczególnych państw oraz dla całej społeczności międzynarodowej. Liczne sukcesy integracji powodują, że liczba organizacji międzynarodowych stale rośnie, zwiększa się również zakres i rodzaj ich działalności.

Stałe zmiany globalizacyjne, które wpływają na wszystkie sfery życia prowadzą do zmian i w branży turystycznej. Działalność Światowej Organizacji Turystyki, która ma na celu w odpowiednim czasie reagować na wyzwania globalizacji, przewidywać i unikać jest szczególnie interesująca.

Istnieje kilka powodów pojawienia się tak dużej liczby organizacji międzynarodowych. Należy wyróżnić dwa zasadnicze: proces globalizacji i ekspansja geograficzna demokracji, które przebiegały jednocześnie. Próbując określić przyczyny globalizacji trzeba połączyć je z wydarzeniami historycznymi, m.in. odkryciem

${ }^{2}$ H. Kissinger, World Order, London 2014, s. 302.

3 G. Ritzer, G. Martin, Globalization and International Terrorism, Malden 2008, s. 644-649.

${ }^{4}$ J. Osterhammel, N.P. Petersson, Globalization: A Short History, Princeton 2005, s. 153.

5 R. Robertson, Globalization Theory 2000+: Major Problematics, [w:] Handbook of Social Theory, red. G. Ritzer, B. Smart, London 2001, s. 458-471.

${ }^{6}$ P. Haggett, Geography: A Global Synthesis, Harlow-New York 2001, s. 668.

7 A. McGrew, D. Held, Globalization Theory: Approaches and Controversies, Oxford 2007, s. 210.

${ }^{8}$ W. Sztumski, Globalizacja-lęk przed nieznanym, ryzyko nadziei, [w:] Narody stowiańskie wobec globalizacji, red. A.L. Zachariasz, Rzeszów 2003, s. 54-80.

${ }_{9}$ О. Краєвська, Політика Європейського Союзу у сфері туризму: концептуальні засади та

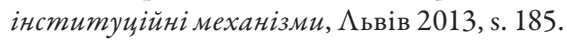

${ }_{10}$ М. Аукашевич, Соиіологія туризму, Ужгород 2008, s. 155.

11 А. Панарин, Глобализация, Київ 2003, s. 183-185.

12 С. УАовик, Глобализачия: Семиотические подходъ, Київ 2002, s. 290.

13 М. Шепєлєв, Теорія міжнародних відносин, Київ 2004, s. 535.

${ }_{14}$ Ю. Яковец, Глобализащия и взаимодействие цивилизащий, Москва 2003, s. 203. 
Ameryki w 1492 r. przez Krzysztofa Kolumba, co było spowodowane chęcią uzyskania dostępu do deficytowych w Europie towarów oraz poszukiwaniem drogi do Indii z pominięciem arabsko-weneckiego monopolu. Odkrycie to miało znaczący wpływ na sposób postrzegania i rozumienia świata, motywując ówczesnych władców do finansowania dalszych wypraw. Wydarzenie to doprowadziło do rywalizacji geopolitycznej na kontynencie europejskim, która koncentrowała się na osiągnięciu dominacji na morzach i zdobywaniu nowych kolonii.

Drugim ważnym wydarzeniem, powodującym powstanie istotnych czynników wzmocnienia tendencji globalizacyjnych była rewolucja przemysłowa w końcu XVIII i na początku XIX wieku. Nowe odkrycia spowodowały bezprecedensową poprawę procesów produkcyjnych, co przede wszystkim pozwoliło rozpocząć wytwarzanie towarów taniej, szybciej i lepiej. Rewolucja przemysłowa przyczyniła się także do napięć politycznych, które w dużej mierze były spowodowane obawami przed gospodarczą hegemonią Wielkiej Brytanii.

Trzecią istotną przyczyną globalizacji był kryzys gospodarczy w 1929 r., który powstał w USA i szybko rozprzestrzenił się na kraje europejskie. Właśnie wtedy po raz pierwszy pojawiła się konieczność stworzenia zasad kompleksowego wpływu państw na rozwój gospodarczy, stymulowanie reform strukturalnych i nadanie tym procesom właściwego kierunku. Skutkami wymienionych przyczyn stały się: stopniowa niezdolność krajów do rozwiązywania coraz większej liczby problemów z różnych dziedzin życia społecznego oraz zwrócenie uwagi na przestrzeganie praw człowieka. Nowy przełom w tej dziedzinie nastąpił wraz z wynalezieniem i popularyzacją internetu, który umożliwił organizacjom międzynarodowym prawie nieograniczone możliwości wpływu na kształtowanie międzynarodowej opinii publicznej.

Tak zwana pierwsza globalizacja ${ }^{15}$, albo „piękna epoka”, to okres od 1860 do 1913 r., który doprowadził do bezprecedensownych dynamicznych zmian we wszystkich sferach - od technologicznej, ekonomicznej, społecznej i demograficznej do kulturowej. Na szczególną uwagę zasługiwały osiągnięcia w dziedzinie technologicznej (prąd elektryczny, maszyny parowe, dynamit). Był to także czas sprzyjający nawiązywaniu współpracy międzynarodowej w nowych dziedzinach: połączenie kolejowe, łączność telegraficzna i meteorologia. Biorąc to pod uwagę, trzeba było stworzyć nowe organizacje, które mogłyby koordynować tę współpracę i stworzyć nowe ramy prawne.

„Druga globalizacja” rozpoczęła się po II wojnie światowej i rozprzestrzeniła na początku XXI wieku. Charakteryzuje się konsekwentnym osłabieniem roli pań-

15 Kompendium wiedzy o organizacjach międzynarodowych, red. P. Deszczyński, E. Łaźniewska, Warszawa 2011, s. 125. 
stwa: niekontrolowane migracje, terroryzm międzynarodowy, ekologia. Świadczy to o tym, że państwa ograniczyły w pewnym sensie zakres swojej suwerenności. W takich okolicznościach zaczęły powstawać i skutecznie działać organizacje międzynarodowe które wypełniły te luki.

Proces ekspansji geograficznej demokracji, rozpoczęty po I wojnie światowej, stał się znacznie bardziej dynamiczny po upadku komunizmu w latach dziewięćdziesiątych. Swobodne funkcjonowanie organizacji międzynarodowych jest potwierdzeniem istnienia w państwach członkowskich demokratycznie dojrzałej formy rządów. Wszelkie próby ograniczenia ich działalności wskazują fasadowość demokracji.

Nowoczesny proces globalizacyjny to zjawisko wieloaspektowe. Biorąc to pod uwagę, badanie istoty globalizacji i jej skutków odbywa się przy użyciu narzędzi metodologicznych różnych dyscyplin naukowych, by na podstawie dedukcyjnej metody badania problemu można było osiągnąć pożądaną jakość dyskursu akademickiego. Jest to jednym z głównych wymagań w procesie budowania modeli teoretycznych. Należy podkreślić, że niektóre obszary znajdują się w dużej interakcji, co uniemożliwia określenie wyraźnych granic między nimi. Na proces globalizacji znaczący wpływ bowiem mają zmiany, które znajdują się w sferach: politycznej, ekonomicznej, technologicznej i społeczno-kulturalnej.

Taki stan rzeczy jest przeszkodą na drodze budowy przyczynowo-skutkowego modelu, który wyjaśniłby specyfikę istniejących współzależności. Proces globalizacji w szerokim rozumieniu obejmuje relacje między podmiotami współczesnych stosunków międzynarodowych. Przede wszystkim są to państwa, organizacje międzynarodowe i korporacje ponadnarodowe. Współpracując i rywalizując między sobą biorą one czynny udział w toku tworzenia ustroju instytucjonalnego, w którym istnieje przestrzeń dla powstania nowych związków.

Interpretacja pojęcia globalizacja nie może nie brać pod uwagę współpracy politycznej, gospodarczej i innych sfer życia. Istotnie utrudnia to określenie jej głównej przyczyny i tworzenia odpowiednich narzędzi, za pomocą których możliwe byłoby nadanie jej właściwego kształtu i kierunku. Poza tym istniejące współzależności często mają charakter asymetryczny i w różnych okolicznościach pojawiają się ze zmienną intensywnością. Żadna z tych sfer nie ma wyraźnego charakteru dominującego, wręcz przeciwnie, w każdej z nich może powstać nowe napięcie, działające na inne sfery.

W naukowych badaniach międzynarodowych relacji utrwalony jest pogląd, że proces formowania współczesnego środowiska międzynarodowego rozpoczął się pod koniec wojny trzydziestoletniej, podpisaniem pokoju westfalskiego w $1648 \mathrm{r}$. Sprzyjało to szukaniu przez państwa nowych form współpracy, spośród których 
najbardziej widoczną okazały się organizacje międzynarodowe. Według W. Morawickiego, do najbardziej ważnych warunków ich tworzenia, a także dynamicznego rozwoju należą:

- polityczne i ekonomiczne motywy (wzmocnienie międzynarodowej współpracy, współzależności, rozwój światowego rynku);

- przekonanie co do korzyści współpracy;

- uświadomienie władzom zgodności interesów;

- możliwość zawierania umów ${ }^{16}$.

Turystyka jest trudnym zjawiskiem, który wpływa na życie milionów ludzi na całym świecie. Determinuje wiele aspektów społeczno-gospodarczych, zapewnia miejsca pracy, kształtuje środowisko, politykę państwa itd. Skutkiem globalizacji jest właśnie wpływ jaki ma turystyka na politykę: nowe technologie, pogorszenie stanu środowiska, powodują konieczność międzynarodowej współpracy na tej płaszczyźnie. Globalny czynnik stwarza, z jednej strony, warunki dla bardziej dynamicznego rozwoju turystycznego przemysłu, $\mathrm{z}$ drugiej strony powoduje problemy, z którymi zmierzyć się musi społeczeństwo.

Na poziomie międzynarodowym skuteczną realizację polityki turystycznej zabezpiecza Światowa Organizacja Turystyki (UNWTO), która sprzyja międzynarodowej współpracy branży turystycznej w walce z głównymi problemami. Konieczność tworzenia i realizacji wspólnej polityki na poziomie międzynarodowym, regionalnym i krajowym wywołuje pozytywne i negatywne skutki. Do takich, według UNWTO, można zaliczyć: wykorzystanie naturalnych zasobów, rozwój infrastruktury, planowanie terytorialne, zatrudnienie społeczeństwa, dochody, zróżnicowanie społecznej struktury, wolny czas, zachowanie zabytków, czynnik kulturowy ${ }^{17}$.

Głównymi kierunkami realizacji efektywnej działalności UNWTO pod wpływem procesów globalizacyjnych są:

1. Instytucjonalna współpraca, której celem jest budowa stałego i konkurencyjnego sektora turystyki, koniecznego dla sprawnej organizacji partnerskich kontaktów z różnymi członkami procesu turystyki. Dla osiągnięcia tego celu Światowa Organizacja Turystyki współpracuje z innymi organizacjami i specjalistycznymi instytucjami na następujących płaszczyznach:

- stały rozwój turystyki na trasach tematycznych, co sprzyjało rozpoczętym w 2012 r. negocjacjom zwiększenia liczby Europejskich Szla-

${ }_{16}$ W. Morawiecki, Międzynarodowe organizacje gospodarcze, Warszawa 1987, s. 15-32.

${ }_{17}$ Sustainable Development of Tourism, http://dtxtq4w60xqpw.cloudfront.net/sites/all/files/ docpdf/sustainability.pdf, odczyt z 1.12.2011. 
ków Kulturowych Rady Europy i opracowaniu planu działania na przyszłość,

- rozwój związków z instytucjami turystycznymi, których celem jest wzmacnianie swej obecności na poziomie państwowym,

- rozszerzanie związków z innymi organizacjami, której celem jest międzynarodowa współpraca, między innymi z Niemiec i Stanów Zjednoczonych,

- podpisanie umowy z Europejską Komisją Transportu i Turystyki, której celem jest wzmacnienie wspólnych działań, skierowanych na rozwiązywanie głównych problemów i globalnych wyzwań, które stoją przed branżą turystyczną.

2. Współpraca subregionalna, charakteryzująca się poszukiwaniem nowych form wspólnej działalności, m.in. tworzeniem związków państw regionu: Morze Czarne, Morze Bałtyckie, Morze Śródziemne, Morze Adriatyckie lub region dunajski. Polegać one mają na wymianie doświadczeń i praktycznej działalności takiej, jak stymulacja rozwoju wspólnych produktów i tras turystycznych.

3. Wzrost potencjału przez wymianę wiedzy i doświadczeń, tworzenie sieci turystycznych powiązań, pozyskiwanie wsparcia politycznego. Światowa Organizacja Turystyki zorganizowała cykl seminariów poświęconych podwyższeniu potencjału pracowników tej branży. Działalność szkoleniową prowadzi organizacja Themis ${ }^{18}$. Skierowana jest zarówno do urzędników krajowych instytucji turystycznych oraz przedstawicieli prywatnego sektora.

Ogólnie działalność UNWTO poświęcona jest wzrostowi turystyki, zwiększaniu jej znaczenia oraz tworzeniu bazy materialno-technicznej. Organizacja stara się usprawnić działania władz w branży turystycznej przez opracowanie i wprowadzenie reguł do turystyki międzynarodowej. Jednym z jej głównych osiągnięć jest stworzenie Globalnego Kodeksu Etyki w Turystyce (1999) jako zbioru podstawowych zasad, które mają na celu zwiększenie korzyści społecznych i ekonomicznych dla całej branży, minimalizując jednocześnie negatywne skutki. Kodeks określa podstawowe zasady dla wszystkich podmiotów, które działają na tym rynku.

UNWTO pomaga państwom członkowskim w ustanawianiu i wspieraniu współpracy między nimi. Równie ważne jest utrzymanie relacji partnerskich z licznymi organizacjami: Europejską Komisją Podróży, Zrzeszeniem Międzynarodowego Transportu Lotniczego, Arabską Organizacją Turystyki, Stowarzyszeniem Tury-

18 Themis Foundation Organization, http://themis.unwto.org/, odczyt z 15.10.1998. 
stycznym Azji Pacyficznej w celu przeprowadzenia wspólnych działań i rozszerzenia strefy wpływów. Na szczególną uwagę zasługuje współpraca ze Światową Radą Podróży i Turystyki, która jest globalnym organem reprezentującym sektor prywatny.

Ponadto Światowa Organizacja Turystyki pomaga w zwiększeniu rozwoju gospodarczego, utrwalaniu pokoju, dorobytu, wzrostu porozumienia między narodami, powszechnego poszanowania i przestrzegania praw człowieka i podstawowych swobód niezależnie od płci, języka i religii.

Globalizacja jest procesem, który sprzyja procesom współzależności, a turystyka jest jednym z jego charakterystycznych przejawów. Sprzyja on także współpracy ekonomicznej i porozumieniu między narodami. W tym kontekście turystyka odgrywa także istotną rolę.

Globalizacja jest częścią codzienności, a związane z nią tendencje mogą mieć fundamentalne znaczenie dla rozwoju międzynarodowej sytuacji politycznej. Potrzeba powstania organizacji międzynarodowych i ich rola w procesie globalizacji sprzyja walce ze światowymi problemami we wspólnym działaniu państw.

Żadna organizacja międzynarodowa nie może jednak działać nie uwzględniając licznych zmian. Światowa Organizacja Turystyki osiągnęła sukces swojej działalności, jednak we współczesnych warunkach stałych zmian globalizacyjnych, zmieniających się potrzeb turystów i szeregu zagrożeń, które powstają w branży turystycznej, zmuszona jest do szybkiego reagowania i tworzenia krótko- i długoterminowych planów. Jej priorytetem powinna być współpraca w ramach ONZ, co pozwoli na utrzymanie stałych kontaktów, informowaniu i realizacji wspólnych projektów w różnych regionach świata.

Celem UNWTO jest więc organizacja branży turystycznej przez rozwój i wprowadzenie zasad do strefy międzynarodowej turystyki. Tworzy więc akty prawne i kontroluje ich wykonanie co sprzyja rozwiązywaniu problemów w turystyce.

Polityka Światowej Organizacji Turystyki jest efektywna. Szybko i sprawnie reaguje bowiem na częste zmiany potrzeb rynku, a zwłaszcza turystów. Jej działalność uświadamia konieczność harmonijnego połączenia krótkoterminowych wyzwań z długoterminowymi planami stałego rozwoju. Reguła ta powinna stać się integralną częścią globalnej i krajowej strategii i polityki turystycznej. 